\title{
Cancer Incidence and Prevalence: A Comparison of Young with Old Population by Review of Literature
}

\author{
Tanushri Mukherjee* \\ Department of Pathology, Command Hospital, India
}

Submission: March 26, 2018; Published: May 18, 2018

*Corresponding author: Tanushri Mukherjee, Oncopathologist, Department of Pathology, Command Hospital, Chandimandir, Panchkula, Haryana, India, Email: tanujamukherjee@yahoo.com

\begin{abstract}
Background: There has been no documented study till date in literature comparing the Cancer incidence and prevalence in young with old in general population.

Methods: This article based on studies of screening and diagnostic tests. I analyzed and compared the incidence of cancers from duration May 2013 to May 2017. The total number of Cancers analyzed in the young patients 23-40yrs with average mean age of 35 was 432 . The total number of Cancers analyzed in the old age group was 743. The results were then compared with the results from the review of literature.

Results: The Cancers common in young age group are hematolymphoid malignancies including acute myeloid leukemias and Non Hodgkin lymphoma, K Ras positive and MSI low colon cancer, astrocytic tumors of brain, testicular tumors, urothelial cancers, oropharyngeal cancers. The Cancer type common in the old age group population is thyroid, lungs, gastric, esophageal, Diffuse large B cell lymphoma, urothelial carcinoma, breast cancers.
\end{abstract}

Conclusion: Stress in addition to genetics factors in young population can be a precipant for causing cancers which is documented in literature and yoga, meditation and boost of immune system can have protective effect in preventing cancers.

Keywords: Serving soldiers; Carcinoma; Sarcoma; Leukemia; Lymphoma

\section{Introduction}

The Cancer incidence, type and prevalence is related to exposure to factors [1] such as physical fitness, dietary compulsions, stress, smoking, alcohol consumption, sunlight exposure, immunizations, radiation and genetic factors influence cancer risk among military personnel. The young population is supposed to be healthier because of regular medical examinations and easy access to health care nowadays. The elucidation of differences in cancer incidence patterns between the young and old population may lead to a better understanding of etiology and the development of preventive strategies for both populations. The current study was conducted to see the incidence and prevalence of cancers, see the type of cancer to correlate with the etiology and to suggest the preventive measures and suggest tools for early screening and detection.

\section{Material and Methods}

This article is based on studies of screening and diagnostic tests. I analyzed and compared the incidence of cancers from duration May 2013 to till date in the young and old populations. The total number of Cancers analyzed in the young population for the duration May 2013 till date was 342. The total number of Cancers analyzed in the old populations for the duration May 2013 till date were 743. For this study, data analyses were confined to male patients only to avoid gender bias due to selection of male personnels only. The results were then compared with the results of various studies from the review of literature [2-5].

The patients were divided into 3 groups based upon the clinical suspicion and presenting complaints and examination. Group I -young patients $n=342$ patients, Group II- Old patients $\mathrm{n}=743$. Group III Normal controls with no suspected malignancy $\mathrm{n}=50$. A complete proforma was prepared noting the complete history of the patient along with the presenting complaints with any other ancillary tests performed. The clinical history and cancer characteristics including tumor type, histological grade, tumor size and lymph node (LN) status. Thin paraffin sections $(2-4 \mu \mathrm{m})$ were obtained from the paraffin blocks and stained with haematoxylin and eosin and histomorphologically evaluated by light microscopy. Immunohistochemistry for the tumors were performed as per requirement. Statistical analysis A p value of less than 0.05 was considered to reflect a significant association. The data were compared using the non-parametric Mann-Whitney test at a confidence level of 95\%. Data processing and statistical analysis were performed using Microsoft Office Excel 2007 (Microsoft Corp, Redmond, WA) and SPSS 16.0 software (SPSS Inc., Chicago, Illinois, USA). For all statistical comparisons, a P-value of $<0.05$ was 


\section{Journal of Tumor Medicine \& Prevention}

considered statistically significant. Logistic regression models were estimated for all immunohistochemical markers and combinations, with cross-validation analysis performed to obtain the sensitivities at set specificities of $90 \%, 95 \%$, and $98 \%$.

\section{Results}

Among the cancers examined, the most common among young patients, the age range was 23-40yrs with average mean age of 35 years (Table 1). All males are listed in Table 2 was acute myeloid leukemia which were initially diagnosed by peripheral blood smear and bone marrow and subsequently confirmed by flow cytometry $(\mathrm{N}=80)$, followed by Non Hodgkin lymphoma $(\mathrm{N}=70)$, and astrocytomas of WHO grade II and grade III $(\mathrm{N}=40)$, testicular seminomatous germ cell tumor $(\mathrm{N}=25)$ and Bone and soft tissue sarcomas $(\mathrm{N}=32)$.

Table 1: Showing the age in years in the respective three groups.

\begin{tabular}{|c|c|}
\hline Study Population & Mean Age in Years \\
\hline Group I young patients $\mathrm{n}=342$ & 35 \\
\hline Group II Old patients $\mathrm{n}=743$ & 50 \\
\hline Group III Normal controls $\mathrm{n}=100$ & 35 \\
\hline
\end{tabular}

Table 2: Cancer prevalence in the young population.

\begin{tabular}{|c|c|c|c|}
\hline Type of Cancer & Site & Suspected Etiology & $\begin{array}{l}\text { Group I Serving Soldiers } \\
\qquad \mathrm{N}=342\end{array}$ \\
\hline Adenocarcinoma & colon & $\begin{array}{c}\text { Dietary compulsion, Hereditary mutation of the } \\
\text { APC gene is the cause of familial adenomatous } \\
\text { polyposis, }\end{array}$ & 15 \\
\hline Urothelial carcinoma & bladder & $\begin{array}{l}\text { Cigarette, dyes, Schistosoma, Human papilloma } \\
\text { virus }\end{array}$ & 20 \\
\hline Squamous carcinoma & Tongue & Pan masala, Viral & 15 \\
\hline Acute leukemia & Bone marrow & Radiation & 70 \\
\hline Non Hodgkin lymphoma & Lymph nodes & Virus & 80 \\
\hline Clear cell carcinoma & kidney & Hepatitis C, Tuberous sclerosis & 10 \\
\hline Testicular germ cell tumors & Testis & Genetic & 25 \\
\hline $\begin{array}{l}\text { Unknown primary site metastasis } \\
\text { to liver }\end{array}$ & liver & Genetic & 10 \\
\hline Squamous carcinoma & Buccal mucosa & Viral & 15 \\
\hline Astrocytoma & Brain tumor & Genetic, Occupational high intensity signals & 40 \\
\hline Bone and Soft tissue Sarcomas & Extremities & Genetic, Ionizing radiations & 32 \\
\hline Papillary carcinoma & Thyroid & Radiation & 10 \\
\hline
\end{tabular}

Among the cancers examined in the old population, all males are listed in Table 3. The group II selected were all males to avoid bias as the group I was of young patients all males. The common malignancies were Lung non-small cell carcinomas ( $N=160)$, followed by Oral malignancies $(\mathrm{N}=150)$, colon cancers $(\mathrm{N}=100)$ and Bladder malignancies $(\mathrm{N}=50)$. The age range was $40-60 \mathrm{yrs}$ with average mean age of 50 years.

Table 3: Cancer prevalent in the old age population.

\begin{tabular}{|c|c|c|c|}
\hline Type of Cancer & Site & Suspected Etiology & $\begin{array}{c}\text { Group II Ex Servicemen and } \\
\text { Dependents N=743 }\end{array}$ \\
\hline Adenocarcinoma & Gastric & Dietary habits & 30 \\
\hline Adenocarcinoma & Prostate & Hormonal & 20 \\
\hline Urothelial carcinoma & Bladder & Cigarette, dyes, Schistosoma, Human papilloma virus. & 10 \\
\hline Squamous carcinoma & Esophagus & Tobacco, alcohol, hot foods, dyes, Human papilloma & virus (HPV). \\
\hline Squamous carcinoma & Oral cavity & smoking, tobacco chewing, and alcohol consumption & 150 \\
\hline Adenocarcinoma & Colorectal & $\begin{array}{c}\text { Dietary habits, Hereditary mutation of the APC gene is } \\
\text { the cause of familial adenomatous polyposis }\end{array}$ & 100 \\
\hline Renal cell carcinoma & Kidney & Hepatitis C, Genetic & 20 \\
\hline Ductal carcinoma & Breast & Genetic & 5 \\
\hline
\end{tabular}


Journal of Tumor Medicine \& Prevention

\begin{tabular}{|c|c|c|c|}
\hline Chronic myeloid leukemia & Blood & Genetic & 30 \\
\hline Acute myeloid leukemia & Blood & Genetic & 35 \\
\hline Metastatic tumor & Liver, lungs & Genetic & 63 \\
\hline Squamous carcinoma & Lung & Smoking & 160 \\
\hline Bone and Soft tissue Sarcoma & $\begin{array}{c}\text { Retroperitoneum, } \\
\text { extremity }\end{array}$ & Genetic, Ionizing radiations & 20 \\
\hline Glioblastoma & Brain & Genetic & 10 \\
\hline Hodgkin lymphoma & Lymph nodes & Epstein-Barr virus-induced & 10 \\
\hline Non Hodgkin lymphoma & Lymph nodes & $\begin{array}{l}\text { Human T-cell leukemia/lymphoma virus I (HTLV- } \\
\text { 1), Epstein-Barr virus, hepatitis C virus, and human } \\
\text { herpes virus-8 infections, bacteria Helicobacter pylori } \\
\text { Chlamydophila psittaci }\end{array}$ & 20 \\
\hline Hepatocellular Carcinoma & Liver & Hepatotropic viruses, cirrhosis & 20 \\
\hline
\end{tabular}

Table 4: Comparing the commonest malignancies amongst the young (I group $n=342)$ and the group II $(n=743)$ of old patients.

\begin{tabular}{|c|c|c|c|}
\hline \multicolumn{2}{|c|}{ Prevalence of Common Malignancies in Serving Personnels } & \multicolumn{2}{|c|}{$\begin{array}{c}\text { Prevalence of Common Malignancies In) of Exservicemen and } \\
\text { Dependents }\end{array}$} \\
\hline Acute leukemia & 70 & Lung & 160 \\
\hline Non Hodgkin lymphoma & 80 & Oral cavity & 150 \\
\hline Testicular germ cell tumors & 25 & Colon & 100 \\
\hline Astrocytoma & 40 & Metastases & 63 \\
\hline Bone and Soft tissue Sarcomas & 32 & Bladder & 50 \\
\hline
\end{tabular}

\section{Discussion}

Our study found differences in cancer incidence rates and the type of cancers between young and the old general population. Lung cancer, non-small cell tumors including squamous carcinomas rates were significantly higher in the old age group. Cigarette smoking is the single most important risk factor for lung cancer and due to increased physical activity in the military, service persons smoke fewer cigarettes than their counterparts in civil. Prostate cancer not seen in the serving population but was seen in old age group because of age related and hormonal factors. Testicular seminomatous germ cell tumor higher incidence noted among members of the armed forces. Incidence of hematolymphoid malignancies notable acute myeloid leukemia, anaplastic large cell lymphoma(ALK positive), angioimmunoblastic $\mathrm{T}$ cell lymphoma were common in the young pateints whereas diffuse large B cell lymphoma and Hodgkin lymphoma common in the elderly group due to possibly effect of viruses.

I compared the incidence of cancers with study by Badwe et al. [6] who found in India increasing incidence of breast and cervix cancers but in our study all patients were males. Among men, the study found a decline in stomach cancer and the increase in colon cancer which were also agreed upon in other studies and colon cancer was found to be common in the serving age group.

The study supported the findings that lung and oral cancers are also the commonest cancer site among elderly males due to increased tobacco. Long-term or chronic stress if prevalent in serving population is damaging" Cohen states that no-end-in-sight stress can weaken your immune system, leaving you prone to diseases like cancer. It also ups your risk for digestive problems and depression. "Chronic stress also can help cancer grow and spread in a number of ways," Sood says. Stress hormones can inhibit a process called anoikis, which kills diseased cells and prevents them from spreading and chronic stress also increases the production of certain growth factors that increase your blood supply and increase incidence of cancer.

Meditation and yoga helps to prevent unhealthy biological changes and adequate eight hours of sleep each night is a great defense against stress as it strengthens the immune system. At Ohio State University, researcher Dr. Ron Glaser, found that students under pressure had slower-healing wounds and took longer to produce immune system cells that kill invading organisms. Dr. Barry Spiegel, a leader in the field of psychosomatic medicine, found that metastatic breast cancer patients lived longer when they participated in support groups. To conclude it is stressed that young population should be practicing yoga, meditation and be less stressed to avoid weakening the immune system which may cause cancers at an early age [7-10].

\section{References}

1. Fritz A, Jack A, Shanmugaratnam K (2001) International classification of disease for oncology. $3^{\text {rd }}$ World Health Organization, Geneva, Switzerland.

2. Hsing AW, Devesa SS (2001) Trends and patterns of prostate cancer: what do they suggest? Epidemiol Rev 23(1): 3-13.

3. McGlynn KA, Devesa SS, Sigurdson AJ, Brown LM, Tsao L, et al. (2003) Trends in the incidence of testicular germ cell tumors in the United States. Cancer 97(1): 63-70. 
4. Irby K, Anderson WF, Henson DE, Devesa SS (2006) Emerging and widening colorectal carcinoma disparities between Blacks and Whites in the United States (1975-2002). Cancer Epidemiol Biomarkers Prev 15(4): 792-797.

5. Thompson IM, Optenberg S, Byers R, Dove M (1999) Increased incidence of testicular cancer in active duty members of the Department of Defense. Urology 53(4): 806-807.

6. Badwe RA, Dikshit R, Laversanne M, Bray F (2014) Cancer incidence trends in India. Jpn J Clin Oncol 44(5): 401-407.

7. Ries L, Melbert D, Krapcho M (2008) SEER Cancer Statistics Review 1975-2005. National Cancer Institute, USA

This work is licensed under Creative Commons Attribution 4.0 License DOI: 10.19080/JTMP.2018.03.555604
8. Giovannicci E, Wu K (2006) Cancers of the colon and rectum. In: Schottenfeld D, Fraumeni JFJ (Eds.), Cancer Epidemiology and prevention. Oxford, Oxford University Press, India, pp. 809-829.

9. Cunradi C, Moore R, Ames G (2008) Contribution of occupational factors to current smoking among active-duty U.S. Navy careerists. Nicotine Tob Res 10(3): 429-437.

10. Peterson AL, Severson HH, Andrews JA, Gott SP, Cigrang JA, et al. (2007) Smokeless tobacco use in military personnel. Mil Med 172(12): 13001305

\section{Your next submission with Juniper Publishers will reach you the below assets}

- Quality Editorial service

- Swift Peer Review

- Reprints availability

- E-prints Service

- Manuscript Podcast for convenient understanding

- Global attainment for your research

- Manuscript accessibility in different formats

( Pdf, E-pub, Full Text, Audio)

- Unceasing customer service

Track the below URL for one-step submission https://juniperpublishers.com/online-submission.php 